See discussions, stats, and author profiles for this publication at: https://www.researchgate.net/publication/282588135

\title{
Determinants of Malaysia's bilateral trade in the manufacturing sector: A comparison between China and Asean
}

Article in Journal of International Business and Economics · October 2015

DOI: 10.18374/JIBE-15-3.2

\section{CITATIONS}

4 authors, including:

(2) Mui-Yin Chin

Tunku Abdul Rahman University College

15 PUBLICATIONS 34 CITATIONS

SEE PROFILE

$\Rightarrow$ Chin-Hong Puah

University Malaysia Sarawak

156 PUBLICATIONS 817 CITATIONS

SEE PROFILE
158

\section{Cia Ling Teo}

Tunku Abdul Rahman University College

3 PUBLICATIONS 14 CITATIONS

SEE PROFILE

Some of the authors of this publication are also working on these related projects:

Project Tourism in Sarawak: Perspectives of Malaysians, Visitors from Neighboring and Distant Countries View project

Modelling intellectual capital with financial inclusion View project 


\title{
BETERMINANTS OF MALAYSIA'S BILATERALTRADE IN THE MANUFACTURING SECTOR: A COMPARISON BETWEEN CHINA AND ASEAN
}

\author{
Huey-Nee Wong, Tunku Abdul Rahman University College, Malaysia \\ Mui-Yin Chin, Tunku Abdul Rahman University College, Malaysia \\ Cia-Ling Teo, Tunku Abdul Rahman University College, Malaysia \\ Chin-Hong Puah, Universiti Malaysia Sarawak, Kota Samarahan, Sarawak, Malaysia
}

\section{ABSTRACT}

Malaysia relies heavily on international trade to drive its economic growth. Thus, this study aims to Jdentify the determinants of bilateral trade between Malaysia and its major trading partners, namely. ASEAN-4 (Indonesia, the Philippines, Singapore and Thailand) and China. Both time series and panel models are utilised in this study for the period of 1980-2013. Empirical results show that the determinants for the countries under study are similar. The study finds that the development of human capital in Malaysia plays a pivotal role in enhancing and sustaining the trade ties between Malaysia and its major trading partners.

Keywords: Bilateral Trade, Economic Growth, Sustainability

\section{INTRODUCTION}

Malaysia possesses a strong trade orientation history (Khalid \& Webb, 2011); since its independence, it Tas practised liberal policies for trade and foreign capital (Tang, 2013). Hence, Malaysia is involved in trade with many countries. According to Kennedy and Peter (1990), Malaysia's trade openness policy has tansformed it into a trade dependence country and one of the "Asian Tigers". It has a sizable amount of both exports and imports and, therefore, its economic growth is mainly contributed by the external sector (Kennedy \& Peter, 1990). Export emerges as the main catalyst to stimulate economic growth in the short Tun (Yousif, 1999). Thus, with rapid expansion of globalisation in this era, international trade plays a pivotal role in further accelerating Malaysia's economic growth.

As Authukorala and Menon (1996) noted, manufacturing has emerged as the most important sector for Wie Malaysian economy. Based on the Economic Report (2014/15), the manufacturing sector contributed $76.2 \%$ and $58.5 \%$ to total exports and total imports, respectively, in 2013. In addition, exports for most of The manufactured goods in Malaysia registered a surge which resulted in the said exports rising by $7.1 \%$ 172014 from a year earlier (MITI, 2015). It is apparent that the manufacturing sector is crucial in

Walaysia's external sector and, thus, this study will focus on the manufacturing sector.

China has emerged as Malaysia's top trading partner since 2009. In 2014, 14.3\% of Malaysia's total trade 17as contributed by bilateral trade with China (MITI, 2015). China's open door policies since 1979 have Transformed it into one of the world's fastest growing economies. Indeed, China has dominated the East 7ind Southeast Asian production network (Tong \& Lim, 2009). Hence, it has activity participated in free Xade agreements with the Association of Southeast Asian Nations (ASEAN), such as the Regional Comprehensive Economic Partnership (RCEP) and China ASEAN Free Trade Area (CAFTA), which were stablished in 2012 and 2010, respectively. As Malaysia is an ASEAN member, it is believed that Halaysia can reap benefits from China's rise.

Wertheless, ASEAN aims to forge closer economic integration among its member countries (Tan \& Santhapparaj, 2006). According to ASEAN (2014a), intra-ASEAN trade has grown at a fast pace, with an Verage growth rate of $10.5 \%$ annually during the period 1993-2013. As a result, total intra-ASEAN trade basted an increase of more than sevenfold from US\$82 billion after the establishment of the ASEAN Free Iade Area (AFTA) in 1993 to US\$609 billion in 2013. Furthermore, the full establishment of the ASEAN 6onomic Community (AEC) in 2015, which transformed ASEAN into one single market and production 
base, will further strengthen the regional integration and accelerate intra-ASEAN trade growth (ASEAN, $2014 \mathrm{~b}$ ). Because ASEAN is an integral part of Malaysia's development, the above-mentioned free trade arrangement would further enhance trade ties between Malaysia and other ASEAN member countries.

However, Leow and Normee (2009) noted that the 2008 global economic downturn had a negative impact on the Malaysian economy as it has a trade-dependent economy. The situation worsened as world trade grew below 4\% in 2013, which was lower than in the 2008 global economic crisis (MITI, 2015). Furthermore, China's economy was downgraded as it marked the lowest growth rate since the 1990 s. Thus, it is essential for Malaysia to enhance and sustain the trade ties with its major trading partners to maintain the country's dynamic economic growth and remain resilient against external shocks. Therefore, it is vital to study the determinants of bilateral trade between Malaysia and China as well as ASEAN-4. The outcomes of this study provide insights to policy makers in implementing trade policies.

\section{METHODOLOGY}

In this study, the determinants of Malaysia's bilateral trade can be modelled as follows:

Trade $=f\left\{G D P_{j}, G D P, A V E F D I, E D U\right\}$

where, Trade = Bilateral trade between Malaysia $(k)$ and reporting country $(j)$ in manufacturing sector

$G D P_{j} \quad=$ Real gross domestic product (GDP) of trading partner

$G D P \quad=$ Real GDP of Malaysia

$A V E F D I=$ Average of foreign direct investment $(F D I)$ inflow in Malaysia and trading partner

$E D U=$ Enrolment in secondary school

All the variables are in real and logarithm terms. Trade serves as the dependent variable while GDP, $G D P_{j}, A V E F D I$ and $E D U$ serve as the independent variables. GDP and $G D P_{j}$ are selected based on new trade theory and the principles of comparative advantage (Athukorala \& Yamashita, 2005) while AVEFDI is selected based on Dunning's eclectic theory of FDI. In addition, human capital is crucial in determining bilateral trade (Findlay \& Kierzkowski, 1983). According to Lewer and Berg (2008), secondary school enrolment $(E D U)$ is the proxy for human capital. The model above will be subjected to two different tests. First, Johansen and Juselius' (1990) cointegration technique will be adopted to investigate the determinants of bilateral trade between Malaysia and China. Meanwhile, the panel model will be used to examine the determinants for the case of bilateral trade between Malaysia and ASEAN-4 in light of the formation of the AEC, which transformed ASEAN into one single market and production base. All the data used in this study are annual statistics compiled from the World Bank's World Development Indicators and the United Nations (UN) COMTRADE database spanning from 1980 through 2013.

\subsection{Johansen and Juselius' (1990) Cointegration Test}

Johansen and Juselius' (1990) technique of cointegration has been adopted to investigate the presence of long-run relationships among the variables. This method can produce unbiased results if all the variables are integrated in (1). The regression equation for the Johansen and Juselius (1990) cointegration test is as follows:

$$
\Delta Y_{t}=\Pi Y_{t-1}+\sum_{i=1}^{l-1} \Pi_{i} \Delta Y_{t-i}+\mu_{t}+\varepsilon_{t}
$$

where,

$\begin{array}{cc}Y_{t} & = \\ \mu_{t} \text { and } \Pi_{i}(i=1, \ldots l-1) & = \\ \varepsilon_{t} & =\end{array}$

$n \times 1$ vector of $/(1)$ variables

$(n \times n)$ coefficient matrixes where $l$ denote lag length

( $\mathrm{n} \times 1$ ) constant variance

independent and normally distributed errors with zero mean and finite variance 
If the cointegrating relationship among variables is significant, the vector error correction model (VECM) can be derived as below to investigate the causal relationship between the dependent and independent variables:

$\triangle T R A D E_{t}=\alpha_{0}+\sum_{q=1}^{n} \varsigma_{1 q} \Delta G D P_{j t}+\sum_{q=1}^{n} \eta_{1 q} \Delta G D P_{t}++\sum_{q=1}^{n} \dot{\phi}_{1 q} \Delta A V E F D I_{t}+\sum_{q=1}^{n} p_{1 q} \Delta E D U_{t}+$ $\delta_{1} \varepsilon_{t-1}+\mu_{t}$

where, $\quad \varepsilon_{t-1}=$ Error correction term; $n$ denotes the lag length

\subsection{Static Linear Panel Data Model}

The panel model below is constructed to examine the determinants of bilateral trade between Malaysia and ASEAN-4:

$$
T R A D E_{i t}=\beta_{0}+\beta_{1} G D P_{j i t}+\beta_{2} G D P_{i t}+\beta_{3} E D U_{i t}+\beta_{4} A V E F D I_{i t}+\varepsilon_{t}
$$

where,

$$
\varepsilon_{i t}=\lambda_{i}+\mu_{i t}, \mu_{i t} \sim N\left(0, \sigma_{u}^{2}\right)
$$

The static linear panel data model is divided into three types, namely, pooled model (PM), random effect model (REM) and fixed effect model (FEM). Hence, three hypotheses tests will be carried out to determine the most appropriate model. The Poolability F-test as well as Breausch and Pagan Lagrangian multiplier (LM) tests will first be carried out to examine whether PM is appropriate in treating the data. The hypotheses testing for the F-test and LM test are shown in Equations (4) and (5), respectively:

$H_{0}: \mu_{0}=\mu_{1}=\mu_{2}=\cdots \mu_{N-1} \cdots=0$

$$
H_{1}: \mu_{0} \neq \mu_{1} \neq \mu_{2}=\cdots \mu_{N-1} \cdots \neq 0
$$

where,

$$
F \text {-stat }=\frac{\frac{R R S S-U R S S}{\frac{N-1}{U L S S}}}{\frac{U N-N-K}{N T-N}} \quad \begin{gathered}
H_{o}: \sigma^{2}{ }_{\lambda}=0 \\
H_{A}: \sigma^{2}{ }_{\lambda}>0
\end{gathered}
$$

where,

$$
\mathrm{LM}=\frac{N T}{2(T-1)}\left[\sum_{i=1}^{N} \frac{\left(\sum_{t=1}^{T} \hat{\epsilon}_{i t}\right)^{2}}{\sum_{i=1}^{N} \sum_{t=1}^{T} \hat{\varepsilon}_{i t}^{2}}-1\right]^{2}
$$

If the $H_{0}$ is rejected for each test, it implies that PM is inappropriate in treating the data. Thereafter, the Hausman specification test is adopted to further examine whether FEM or REM is more appropriate in treating the data. The hypothesis testing for the Hausman test is shown below:

$$
\begin{gathered}
H_{0}: E\left(\mu_{i t} / X_{i t}\right)=0 \\
H_{1}: E\left(\mu_{i t} / X_{i t}\right) \neq 0
\end{gathered}
$$

$$
\text { Haus }=\left(\hat{\beta}_{f \varepsilon}-\hat{\beta}_{r \varepsilon}\right)^{\prime}\left[V_{f \varepsilon}-V_{r e}\right]^{-1}\left(\hat{\beta}_{f \varepsilon}-\hat{\beta}_{r \varepsilon}\right)
$$

If $H_{0}$ is rejected, it implies that FEM best describes the data and it should be adopted for the econometric estimation and otherwise. 


\section{EMPIRICAL FINDINGS}

\section{The Bilateral Trade between Malaysia and China}

The results of Augmented Dickey-Fuller (ADF) and Phillips-Perron (PP) tests show that all the variables are stationary at first difference. Thus, all the variables are integrated in $1(1)$. Hence, the model is appropriate for the Johansen and Juselius (1990) cointegration test. The findings from the cointegration test signify a long-run equilibrium relationship between the variables under study. Therefore, VECM can be established and the results are shown below:

$$
\text { Trade }=-44.714+\underset{(2.009)^{\star \star \star}}{0}+\underset{(0.6525)}{0.287 \mathrm{GDP}_{j}}+\underset{(0.5807)}{0.374 \mathrm{GDP}}+\underset{(6.052)^{\star \star \star}}{0.125 \mathrm{AVEFDI}}
$$

Figures in parenthesis refer to $t$-statistics. Note that $E D U$ is significant and consistent with the theoretical expectation. The magnitude of EDU at 3.127 implies that the development of human capital in Malaysia has a positive and large effect on the country's bilateral trade in the manufacturing sector. Thus, EDU emerged as the most important determinant for the bilateral trade between Malaysia and China. The result is consistent with Mckibbin and Woo (2003). Also, China's GDP instead of Malaysia's GDP is significant in this study. The result suggests that the bilateral trade between Malaysia and China depends on China's economy. In other words, the current slowdown of China's economy will negatively affect the bilateral trade between the two countries. Nevertheless, the insignificance of AVEFDI implies that FDI is no longer instrumental for Malaysia to enhance its trade ties with China (see Chin, Yong, \& Yew, 2014). In addition, the value of $\varepsilon_{t-1}$ is negative, with a value of 0.223 indicating a moderate speed of convergence to the equilibrium.

\section{The Bilateral Trade between Malaysia and ASEAN-4}

The econometric results of the Poolability F-test, Breausch and Pagan LM test and Hausman specification test used to identify the best model to treat the panel data are presented in Table 1.

Table 1: Results of Static Linear Panel Data Models

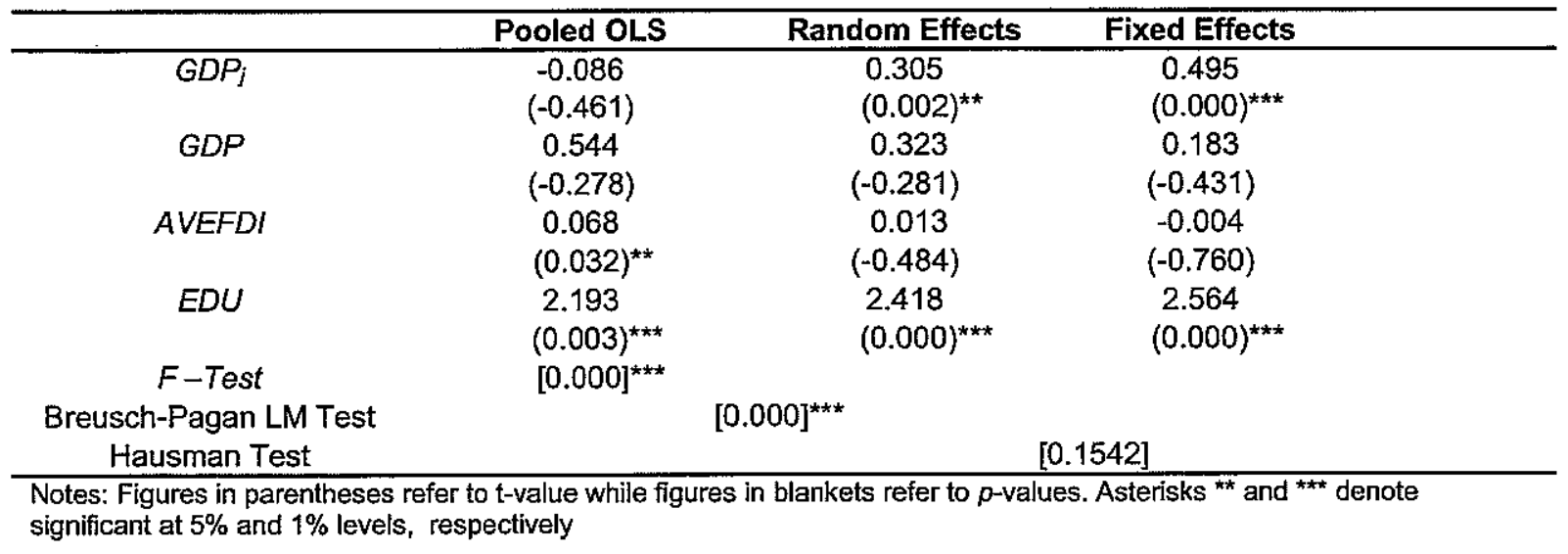

Based on the results from Table 1, the best model to treat the panel data is REM because both the $F$-test and LM test are significant, while the Hausman test is insignificant. Hence, the estimation will be based solely on random effect. The results are found similar with the bilateral trade between Malaysia and China. Although the magnitude of EDU for ASEAN-4 is relatively smaller than that of Malaysia-China trade, the effect of $E D U$ on trade is still greater than twofold. Thus, it signifies the importance of the development of human capital in Malaysia. Also, the GDP of ASEAN-4 also plays an important role in Malaysia-ASEAN-4 trade as the results indicated that a 1\% increase in GDP of ASEAN-4 will result in a rise of bilateral trade between Malaysia and ASEAN-4 of $0.31 \%$. 


\section{CONCLUSION}

This study aims to identify and compare the determinants of Malaysia's bilateral trade with China and ASEAN-4 in the manufacturing sector using annual statistics from 1980 through 2013. The econometric results show that the determinants for bilateral trade between Malaysia-China and Malaysia-ASEAN-4 are similar. Based on the findings, the development of human capital is instrumental in Malaysia's bilateral trade. This implies that Malaysia should focus on high value-added products to sustain the bilateral trade with its top trading partners. Thus, policy makers should implement various plans to motivate the younger generation to pursue higher education and acquire better skills.

Nevertheless, it is also essential for Malaysia to participate actively in any form of activity that will elevate the economic development of ASEAN members as the GDP of trading partners is a positive and significant variable. Hence, the full implementation of AEC in 2015 will accelerate the economic growth of all ASEAN members, which will also indirectly enhance and sustain the trade ties between Malaysia and ASEAN-4 members. Although China has been Malaysia's top trading partner since 2009, the empirical findings show that the trade ties between Malaysia and China depend on China's GDP instead of Malaysia's GDP. Therefore, Malaysia is vulnerable to economic recession in China. As a result, Malaysia should diversify its trading partners to enhance the development of its external sector.

\section{REFERENCES}

Athukorola, P., \& Menon, J. (1996). Foreign investment and industrialisation in Malaysia: exports, employment and spillovers. Asian Economic Journal, 10(1), 29-44.

Athukorala, P., \& Yamashita, N. (2005, Dec). Patterns and determinants of production fragmentation in world manufacturing trade. Paper Presented at the Conference on Globalisation and Regionalism in Australian National University and the European Central Bank, Sydney, Australia.

ASEAN. (2014a). ASEAN Community in figures special edition 2014: A closer look to at trade performance and dependency, and investment. Jakarta: ASEAN Secretariat.

ASEAN. (2014b). Thinking globally, prospering regionally ASEAN Economic Community 2015. Jakarta: ASEAN Secretariat.

Chin, M. Y., Yong, C.C., \& Yew, S. Y. (2014). The determinants of vertical intra-industry trade in SITC 8: the case of ASEAN-5 and China. Proceedings of the Australian Academy of Business and Social Sciences Conference, Kuala Lumpur.

Economic Report 2014-2015. (2014). Ministry of Finance, Malaysia.

Findlay, R., \& Kierzkowski, H. (1983). International trade and human capital: A simple general equilibrium model. Journal of Political Economy, 81(6), 957-978.

Johansen, S., \& Juselius, K. (1990). Maximum likelihood estimation and inference on cointegration: with applications to the demand for money. Oxford Bulletin of Economics and Statistics, 52, 169-210.

Kennedy, J., \& Peter, J. (1990). Malaysia: An alternative pacific export base. International Executive. $31(6), 34-36$.

Khalid Yousif Khalafalla \& Webb., A.J. (2011). Export-led growth and structural change: evidence from Malaysia. Applied Economics, 33, 1703-1715.

Leow, G.Y., \& Normee Che Sab. (2009).Benchmarking Malaysia's manufactured exports competitiveness. Malaysia Journal of Economic Studies, 46(2), 175-200. 
Lewer, J., \& Berg, H (2008). A gravity model of immigration. Management Department Faculty Publications. Paper 22. Retrieved from hitt://digitalcommons.unl.edu/managementfacpub/22.

Mackibbin, W. J., \& WoO, W. T. (2003).The consequences of China's WTO accession for its neighbors. Asian Economic Papers,2 (2), 1-38.

MITI. (2015). MITI report 2014. Ministry of International Trade and Industry, Malaysia.

Tan, C. H., \& Santhapparaj, A.S. (2006). Skilled labor immigration and external trade in Malaysia: A pooled data analysis. Perspectives on Global Development and Technology, 5 (4), 351-366.

Tang, C.F. (2013). A revisitation of the export-led growth hypothesis in Malaysia using the leveraged bootstrap simulation and rolling causality techniques. Journal of Applied Statistics, 40(11), 23322340.

Tong, S.Y., \& Lim, T. S. (2009). SINO-ASEAN economic Integration and its impact on Intra-ASEAN trade. EAl Working Paper No.144.

Yousif Kai-Yousif. (1999). On the role of exports in the economic growth of Malaysia: A multivariate analysis. International Economic Journal, 13(3), 67-73.

\section{AUTHOR PROFILES:}

Huey-Nee Wong obtained her Master's degree (International Economics) from Universiti Putra Malaysia in 2010. Currently she is a lecturer at Faculty of Economics and Corporate Administration in Tunku Abdul Rahman University College.

Mui-Yin Chin obtained her PhD (International Economics) from University of Malaya in 2013. Currently she is a Senior Lecturer cum Programme Leader at Faculty of Economics and Corporate Administration in Tunku Abdul Rahman University College.

Cia-Ling Teo obtained her Master's degree (Finance) from Universiti Putra Malaysia in 2011. Currently she is a lecturer at Faculty of Finance in Tunku Abdul Rahman University College.

Chin-Hong Puah obtained his PhD (Financial Economics) from Universiti Putra Malaysia in 2009. Currently he is an Associate Professor cum Deputy Dean at Faculty of Economics and Business in Universiti Malaysia Sarawak. 